\title{
オノマトペを用いた街歩きによる都市の様相の記述と分析 DEPICTION AND ANALYSIS OF URBAN MODALITY BASED ON CITY WALKS USING ONOMATOPOEIA
}

\author{
北雄 介*1 \\ Yusuke KITA
}

\begin{abstract}
Both the atmosphere and the quality of cities -what we call "urban modality"- have been receiving increasing attention these days. In order to depict urban modality in a visual manner, we conducted a city walk in Yaizu city. 40 participants walked around the city and inputted onomatopoeia using a smart phone app when they grasp modality of the city. We then developed the "Yaizu Onomatopoeia Map" based on the data obtained during the city walk. We analyzed the data and showed that the data were quantifiable and that the data offered information about urban modality in Yaizu city.
\end{abstract}

Keywords : City Walk, Onomatopoeia, Urban Modality, Map Making, Yaizu 街歩き，オノマトペ，都市の様相，地図作成，焼津

\section{1. 序論}

\section{1. 研究の背景と目的}

近年、街歩きの機運が高まっている。芸能人が街をそぞろ歩くテ レビ番組が人気を博し、観光においてもマイカーやバスで名所旧跡 だけを巡るのではなく、それらの間をじっくりと徒歩で回るスタイ ルが増えている。また、そうして街を歩くことで感じられるその街 独自の䨌囲気や質についても関心が持たれている。交通利便性や行 政・教育機関の有無などに加えて、活気やコミュニティの豊かさ、 街のブランド力などが住まい探しの際に重んじられるようになり、 「住みたい街ランキング」も頻繁に話題に挙がる。

つまり現代では、「何がある街なのか」だけではなく「どのような 街なのか」という視点でも都市が見られ、評価されるようになって いる。機能主義的な都市観から、雾囲気や印象などを考慮した都市 の捉え方への移行が進んでいるのである。景観や地域性といった言 葉が度々議論に挙がるのもそのあらわれであろう。しかし、そうし た街の在り方は非常に漠然としており、定量的に計測したり、可視 的に表現したりすることが難しいものでもある。

特に、とりたてて観光名所がない街や知名度の低い街の場合、い かにその雰囲気や魅力を伝えられるのだろうか。本稿がフィールド と寸る静岡県焼津市も、そのような街の一つである。マグロやカツ オの遠洋漁業を中心とした魚の街であるが、よく知られた名所など はなく、観光客や移住者を惹きつけるようなアピールポイントにも 乏しいように思われる。しかし実際に街を歩くと、港湾を中心とし た生活景や海から富士山への眺めなど、この街独自の魅力を見つけ ることができる。このような知られざる魅力をいかに発見し伝える
かは、焼津のような地方都市に共通の課題だと言える。 本稿の目的は、都市の䨌囲気や質を表現する地図をつくる方法論 を開発し、その検証を行なうことである。具体的にはまず、焼津市 において多くの人に街歩きを行なってもらい、焼津の雾囲気を可視 化する地図を作成する。その際の記録ツールとして、主にオノマト ペを用いる。次に、この手法によってどのようなデータが集まり、 街の雰囲気のどのような側面が表現されているのかを分析する。

\section{2. 都市の様相論}

上述した都市の雾囲気や質といったことがらを、筆者らは「都市 の様相」いう語で捉え、研究を展開してきた1),2),3),4)。様相という概 念はアリストテレス以来の歴史をもち、定義も多様であるが、それ らに共通する考え方は、何かの物自体ではなく、その「在り方」を 指すということである。そしてこの語を建築・都市の分野に導入し たのが原広司である。原は、「事物の状態や空間の状態の見えがかり、 外見、あらわれ、表情、記号、雰囲気、たたずまいなどと記録され る現象」を様相と呼んでいる5)。原は様相の概念を、機能に替わる新 しい時代の都市・建築のキーワードに据えている。

筆者らは以上の考え方を引き継ぎ、様相という語を、ものごとの 全体的な在り方（total mode of being）を指すものとして用いてい る。すなわち都市の様相とは、都市の全体的な在り方のことである。 都市の様相は、建物、樹木、人や車のように目に見えるもの、風や 音、におい、そして雾囲気や佇まい、意味などを含んだ総体として 立ちあらわれる。きわめて全体的で未分化な現象である。

都市の様相を理解するためのアプローチは、大きく分けて二つあ る。まず一つは都市の物理的表象に着目する方法である。たとえば
*1 京都大学大学院横断教育プログラム推進センターデザイン学リーデイング大学院 特定講師・工博
Lect., Leading Graduate School of Design, Center for Educational Program Promotion in Graduate School, Kyoto Univ., Dr.Eng. 
原の研究室では街路構造6)、タクシーの運行経路7などの物理的な現 象を分析することで、都市の様相の諸側面を描き出した。もう一方 は物理的表象ではなく、私たちが感じ取っている様相を理解しょう とするアプローチである。人の認識というフィルターを通じて、都 市の様相という曖昧な事象に迫るのである。

筆者らはこれまで、後者の方法で研究を行なってきている。その 方法は以下のものである。まず多くの人に街を歩いてもらい、その 場で人々が把握 (grasp) した様相を、言語などを用いて記録 (record) してもらう。その記録を元に、図表などのかたちで様相を可視的に 記述 (depiction) する。そして記録や記述結果に対し、定量的、定 性的な分析 (analysis) を行なう。このような手続きによって、人々 の捉える都市の様相に対して科学的なアプローチで探求することが できる。本稿も基本的に、以上のような研究手順を踏む。

\section{3. 既往研究と本研究の位置づけ}

これまでに都市の様相という概念を明示してその分析を行なった 研究こそ少ないものの、認識論的アプローチにより都市の䨌囲気や 質を測り、可視化し、分析する試みは多数行なわれてきた。古典と なっているK. Lynchの『The Image of the City』8)に始まり、高速 道路通行時の人の認知を可視化したD. Appleyardらの研究9)、エレ メント想起法により都市のイメージをマッピングした志水の研究10)、 $\mathrm{SD}$ 法などによりシークエンス景観を定量的に分析した船越らの研 究11などが代表例として挙げられる。都市をフィールドとした環境 心理学分野の研究は、広く本研究のテーマと関連していると言える。

街歩きを通じた地図の作成は、近年、特に市民参加の街づくりの 現場において盛んに行なわれている。たとえば田中は、市民と行政 との協働のもと、地域の「幸せ絵巻」という地図を作成するための 街歩きワークショップを開催した ${ }^{12)}$ 。大内は地域の防災マップを、 街歩きワークショップを通じてアップデートしていくプロセスを報 告している13)。また本稿と同椂に、街歩きによる地図作成の手法開 発に重きをおいた研究も見られる。たとえば大森らは、街歩きを通 じて写真と位置情報、自由記述によるテキストからなる「SLoTデー 夕」を取得し、写真の分類やテキストマイニングなどによってデー 夕を可視化、分析した ${ }^{14)}$ 。

本研究も街歩きによる地図作成手法の開発を目指すものであるが、 その際に主にオノマトペを用いるのが、比較的新規性の高いアプロ 一チである。オノマトペは2.1.で後述するように、都市の様相に対す る高い表現力をもち、かつ定量的、定性的な分析が可能である。都 市についてのオノマトペを用いた研究としては、自転車の発する音 のオノマトペを用いて東京の地形を可視的に表現した杉浦らの研究 15)、五感と快・不快に分類したオノマトペの都市地図上へのマッピ ングを試みた仲村らの研究16)があり、いずれも本研究の着想の要因 の一端となっている。しかしこれらの研究ではごく限られた情報の 可視化の試行段階に留まっており、本稿のような街歩きを通じた大 規模なデータの収集や、多角的な分析は行なっていない。

なお言語学や認知科学、情報学の分野では、音韻論や意味論、言 語間比較などの観点で、オノマトペに関する基礎研究が行なわれて きた。近年には食品の歯触りの表現17)、楽曲検索18)などを対象とし てオノマトペの応用を探った研究も見られる。本稿ではこのような、 都市の文脈とは関係なく行なわれてきたオノマトぺ研究の知見も取 り入れながら、論述を進める。

\section{4. 本稿の構成}

2 章では、オノマトペを用いた街歩きによってデータを収集する 方法と、実際の収集結果について述べる。3章ではこのデータを元に 「焼津オノマトペマップ」を作成し、焼津の街の様相を記述する。4 章では、オノマトペを用いた街歩き体験とオノマトペマップに対す る評価をアンケート調查により分析し、街歩きを通じたオノマトペ マップの作成という試みの長所や問題点を探る。5 章では、得られた データを定量的・定性的に分析することで、街歩きとオノマトペに よって都市の様相がどのように表わされうるのかを探る。

\section{2. データの収集}

\section{1. 様相の記録ツールとしてのオノマトペ}

文献1)〜4)に挙げた研究では、京都市内に指定した3つのルートを 被験者に歩いてもらい、把握した様相を自由記述を中心とした方法 で用紙に記録してもらう「経路歩行実験」を行なった。しかし経路 歩行実験では、面的に広がる都市の中で、そのルート上の様相しか わからない。そこで筆者らは、指定ルートの歩行から指定領域内の 自由歩行という方法に切り替え、また記録用のスマートフォンアプ リを開発することで研究の展開を図った。ところが、領域の様相を 記述しそこから一定の傾向を抽出するためには、自由記述の記録内 容はスパース寸ぎて、そのスパースさを補うほどの記録量を得るこ とも難しいことが明らかになった19)。街歩きにおける自由記述デー タのスパースさについては大森らも指摘しているところである20)。

そこで本研究では、参加者による記録内容に制限を加えて、オノ マトペを中心とした記録を行なうことにした。オノマトペは自由記 述に比べて語彙が限られ、データのスパースさを抑制でき、分析も 容易となる。言語学や認知科学の分野でのオノマトペに関する既往 研究の知見も活用できる。またオノマトペは、建物や木々といった 物理的要素そのものではなく、その要素の状態や動き、音、それら に対する人の感じ方などを表現するという特徵がある。深田らは、 オノマトペが事態を分析的に捉えるのではなく、状況の全体を未分 化なまま捉える性質をもつという21)。たとえば「ちやぷちやぷ」と いうオノマトペは、水の表面が波立って音が出ている際に用いられ るが、「水の表面が波立って音が出ている」という分析的な説明なし に、「ちゃぷちやぷ」というオノマトペだけで音や情景をも想起させ る。本研究で用いる様相という概念も、その場の静的・物的状態だ けではなく動きや音をも含んだ、未分化で全体的な在り方を指すも のである。したがって状況の全体を未分化なまま捉えるオノマトペ は、様相を端的に表現するのに適していると言える注1)。

さらに、オノマトペを探して街を歩くという行為自体にゲーム性 や非日常性がある。街歩きの参加者に楽しんでもらえて、多くのデ ータが集まるのではないかと期待した。

\section{2. アプリ「100ninmap」}

捉えた様相の記録のために、筆者らが以前より開発しているスマ ートフォンアプリ「100ninmap」を、今回の街歩き用にカスタマイ ズして利用した。このツールの概要を説明する。

参加者はスマートフォン（iOSまたはAndroid搭載）を持って街を 歩く。何か表現したいことがあったとき、(1)オノマトペ（平仮名、 片仮名、一部の記号のみ入力可能)、(2)そのオノマトペの説明文 (自 由記述)、および(3)そのときの印象評価（「-2: 悪い」〜「+2:よい」 
の5段階) という3つのデータを入力し、発信する (Fig. 1左)。オノ マトペだけではなく説明文と印象評価を加えることで、分析を深め ることを意図した。なおこの発信は「Twitter」注2)になぞらえて「つ ぶやき」と呼んでいる。つぶやきデータは(4)ユーザー名と、スマー トフォンによって取得される(5)位置情報、(6)時間情報とともにサー

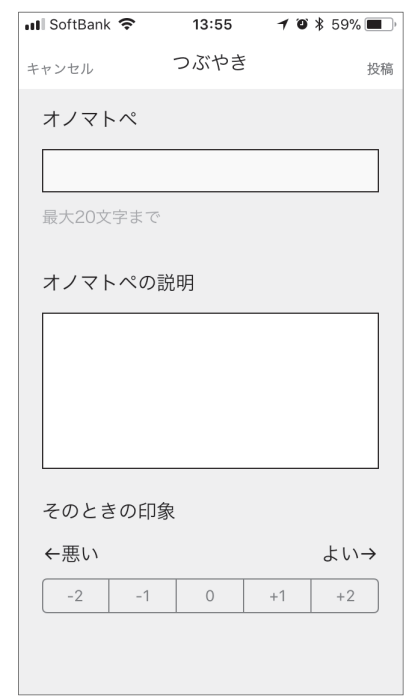

つぶやき画面 tweet screen

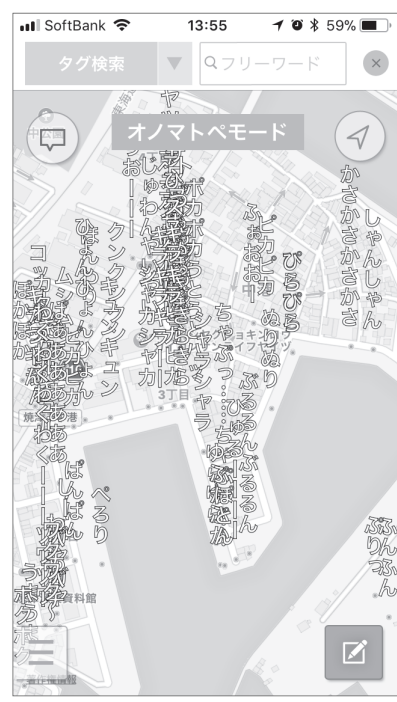

地図画面 map screen
Fig. 1 Screenshot from the app "100ninmap" アプリ「100ninmap」のスクリーンショット
バーに送られる。

すると、その位置情報に応じて、参加者のつぶやいたオノマトペ が地図上に自動的にプロットされる（Fig. 1右）。画面上でオノマト ペをタップすると、説明文とユーザー名が表示される。時間が経つ につれてオノマトペがどんどんと地図上に蓄積され、参加者も随時 その様子を確認することができる。

\section{3. 街歩きの実施}

街歩きは静岡県焼津市にて、2017年2月2日に行なった。冬季では あったがよく晴れ、終盤には参加者は暑さを感じたというほどで、 寒さによる悪影響はほぼなかったと考えられる。参加者は40名で、 大学学部生36名（男性11名，女性25名）、高校生3名（女性3名）、社 会人 1 名（男性 1 名）という構成であった。

参加者は焼津市役所に集合し、街歩きの趣旨やアプリの使い方な どの教示を受けた後、11:00頃に出発し、15:00までの約4時間、指定 範囲 (約 $2.4 \mathrm{~km} \times$ 約 $1.8 \mathrm{~km}$ ) 内を自由に散策しながら、つぶやきを発 信した。参加者にリラックスした感覚で歩いてもらうために、一人 で歩いても複数人で歩いても、途中に休憩や食事を取ることも自由 としている。また参加者をチームに分け、つぶやきの多かったチー ムなどに賞を与えることで、モチベーションを高めることを試みた。 結果的に、合計533のつぶやきを得ることができた。一人あたりの つぶやきの件数は最高 42 件から最低 2 件までのばらつきがあり、参 加者全員のモチベーションを上げられなかったことは反省材料であ る。とはいえ、様相の記述や分析に足るような、一定量のデータを

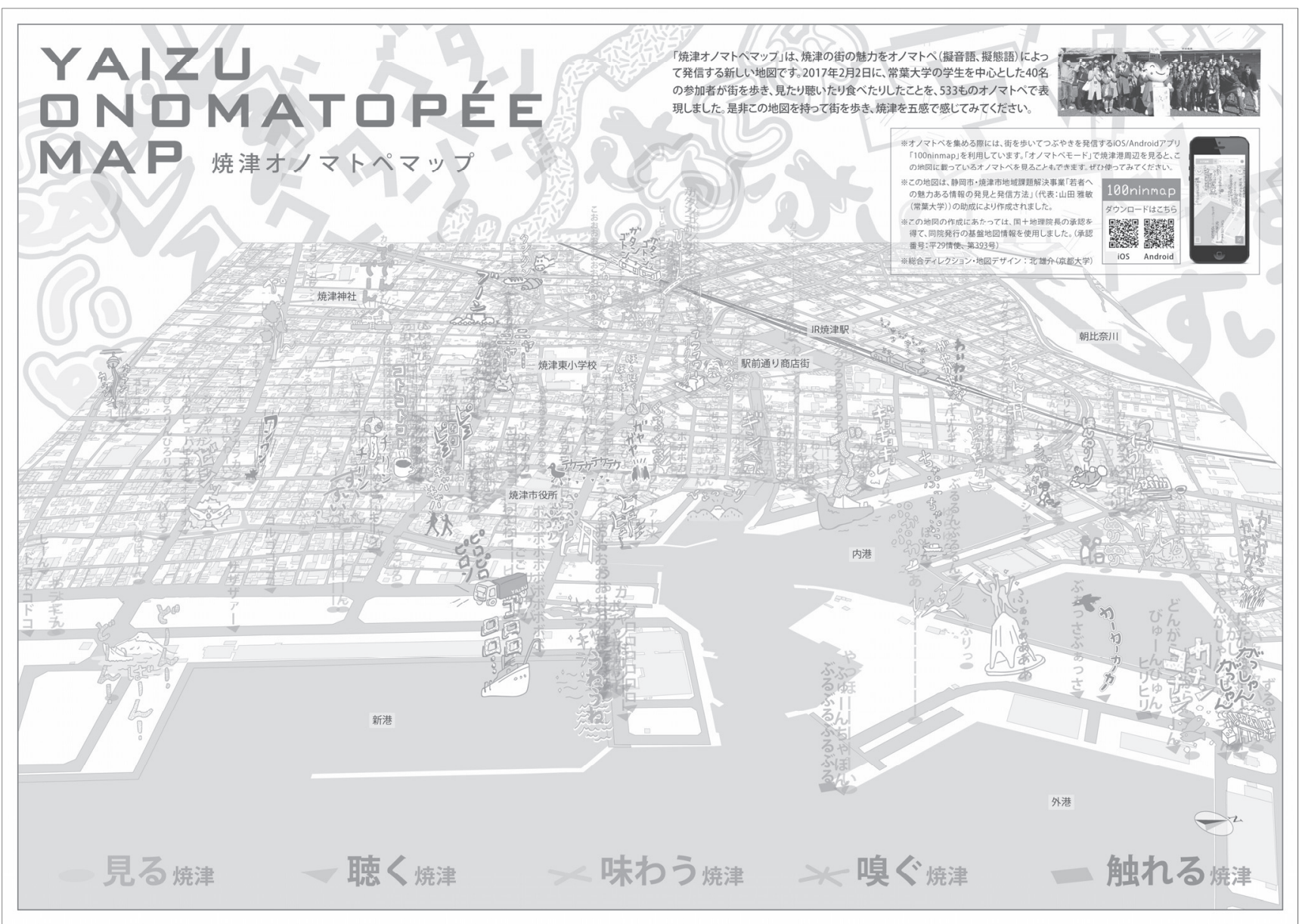

Fig. 2 The Yaizu Onomatopoeia Map 焼津オノマトペマップ 


\section{得ることはできた注3)。}

\section{3.「焼津オノマトペマップ」の作成}

得られたつぶやきデータは、焼津の街の様相を記録したものであ る。そしてアプリで自動的に生成されるFig. 1自体が、オノマトペを 用いた様相の記述になっている。しかしこの状態では、オノマトペ が何を指しているのか（オノマトペの説明）はアプリ上でオノマト ペをタップしなければわからない。またそもそもスマートフォンと アプリがないと、この地図自体を見ることができない。オノマトペ を用いた地図のさらなる表現可能性を探るために、また焼津の魅力 を広く伝えるという実践的目的のためにも、つぶやきデータを編集 して紙の地図を作成することにした。

具体的には以下のことを行なった。まずオノマトペを五感に分類 し注4)、感覚別に色分けした。次に、焼津の街の様相をよくあらわし ていると思われる代表的なオノマトペを選出し、つぶやきの説明文 も参考にしながら、オノマトペとそれが指寸意味内容をイラスト化 した。そしてこれらを、焼津を太平洋側（東側）の上空から見たよ うなパースのかかった地図の上にプロットした。完成した「焼津オ ノマトペマップ」がFig. 2である。本誌ではモノクロでの掲載となる が、カラー版をweb上に公開している注5)。

このオノマトペマップは、名所や店舗などをプロットした従来の 観光地図とは異なる、新しいタイプの地図である。街の客観的な情 報はほとんど記されていないものの、都市の様相を伝える地図にな っているのではあるまいか。この効果は4.2.において検証する。

\section{4. 本研究の試みに対する評価}

\section{1. 街歩き体験の評価}

街歩き参加者の体験は、街を歩いて、オノマトペで表現したいも のごとをアプリでつぶやき、アプリ上で進化する地図を見てまた歩 く、というものであった。この体験がどのようなものであったのか を検証するため、終了後にその感想を5段階評価とオノマトペ (Fig. 3)、自由記述（Table $1^{\text {注6) }}$ ）によって訪ねた。

5段階評価のうち下位 2 段階を回答した参加者はなく、今回の街歩 き体験への評価は非常に高い。また自由記述からは、歩き疲れはし たものの、知らない街のいろいろな場所を歩けて発見があり、街歩 きを楽しめたということがわかる。オノマトペという記録形式につ いては、難しくはあるものの、その非日常の体験を楽しんだ参加者 も多かった。この点は、オノマトペを用いた街歩きという企画の狙 い通りであった。ただし、つぶやく行為に関するコメントは多かっ たのに比べ、アプリ上に自動生成されるマップについては感想が少 なかった。進化するマップを見て楽しみ、歩き方を考えるというよ うなインタラクションはあまり起こらなかったと考えられる。

\section{2. 焼津オノマトペマップの表現の評価}

次に、Fig. 2のオノマトペマップがいかに街の様相を伝えている かを検証するため、一対比較法による調查を行なった。対象は大学 学部生 38 名である（男性 29 名、女性 9 名、街歩き参加者との重複は1 名)。A.焼津市で現在配布されている一般的な観光地図、B.アプリ 「100ninmap」の見た目に近い、オノマトペを配置しただけの地図、 C. Fig. 2のオノマトペマップという3種類の地図（Fig. 4）をスクリ ーンで映示し、一対比較（中屋の変法）をしてもらった。比較は「街

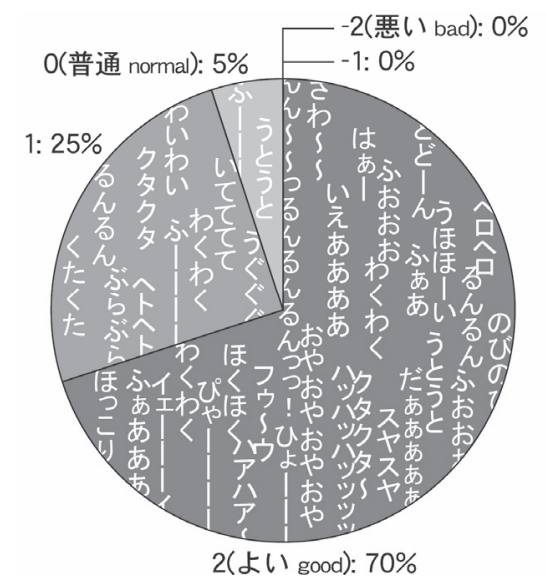

Fig. 3 Impressions of the experiment (onomatopoeia and 5gpoint evaluation) 実験の感想（オノマトペと5段階評価）

Table 1 Impressions of the experiment (free writing) 実験の感想（自由記述）

\begin{tabular}{|l|c|}
\hline \multicolumn{1}{|c|}{$\begin{array}{c}\text { 内容 } \\
\text { content }\end{array}$} & $\begin{array}{c}\text { 回答数 } \\
\text { number }\end{array}$ \\
\hline 楽しかつた It was fun. & 24 \\
\hline 歩き疲れた、よく歩いた I was tired from walking, I walked a lot. & 17 \\
\hline $\begin{array}{l}\text { アプリや街歩きへの改善提案 Suggestion for improvements to app and city } \\
\text { walk. }\end{array}$ & 10 \\
\hline 発見や新しい経験があつた There was discovery and new experiences. & 9 \\
\hline 知らない街を歩けた I could walk down streets I did not know. & 8 \\
\hline いろいろな場所を歩けた I could walk around various places. & 8 \\
\hline 食を楽しめた I enjoyed the food. & 7 \\
\hline オノマトペでの記録は面白い Recording on Onomatopoeia is fun. & 6 \\
\hline オノマトペでの記録は難しい Recording on Onomatopoeia is difficult. & 4 \\
\hline 音をよく聞けた & 4 \\
\hline
\end{tabular}

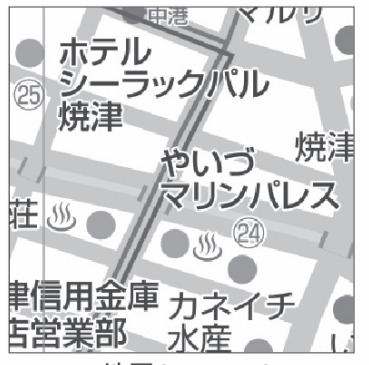

地図A map A

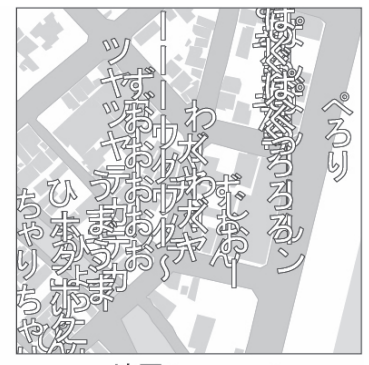

地図B map B

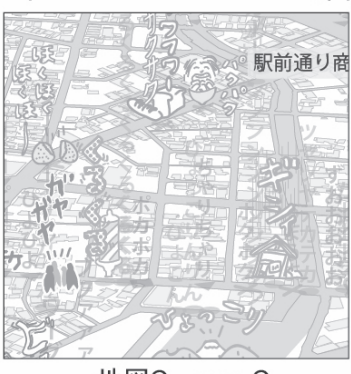

地図C map C

Fig. 4 The three types of maps shown in the comparative survey (part) 比較調査で示した3種類の地図（部分）

の情報がわかりやすい (以下[情報])」「街の雾囲気がわかりやすい (以下[雰囲気])」「街を歩いてみたくなる（以下[歩き]）」という3つ の観点について、7段階評価とした。指標の選定理由は、[情報]につ いては従来的な地図がもっとも重点を置いて表現していると考えら れること、[雾囲気]については今回オノマトペマップで表現したか ったことであり、また[歩き]は地図が街歩きへの誘因力を持ってい るかを調べるという意図に基づいている。他に、 $\mathrm{A} 、 \mathrm{~B} 、 \mathrm{C}$ のそれぞ 


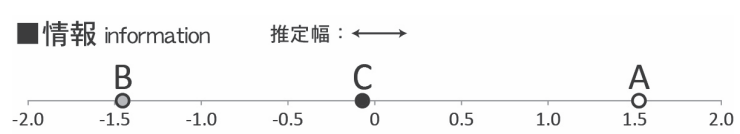

口雾囲気 atmosphere 推定幅 :
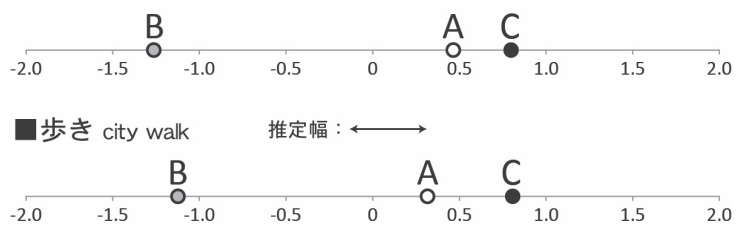

Fig. 5 Scale diagram of the results of the comparative survey 比較調査の結果の尺度図

れの地図から受ける印象を、自由記述で尋ねた。

得られた尺度図をFig. 5に示寸。[情報]でA $>C>B$ 、[雾囲気]と[歩 き]で $\mathrm{C}>\mathrm{A}>\mathrm{B}$ という結果となっている。街にどのようなものがある のかという[情報]では従来の地図が大きく勝るが、オノマトペマッ プは[雰囲気]がよく伝わり、[歩き]たくなるというように受け取られ ている。オノマトペマップの狙いは概ね達成された。ただし[雾囲気] や[歩き]での $\mathrm{C} と \mathrm{~A} と の$ 值の差は小さく、改善の余地は残っている。

自由記述を見ると、どの指標でも值の低かったBでは、「文字が重 なってごちゃごちゃしている」「何があるのかわからない」という回 答が目立った。分類とイラスト化を行なったCでは「何があるのか がBよりわかりやすくなった」という回答が多く、オノマトペとそ れが表わしている意味内容を絵で示すことの有効性が明らかになっ た。他に「楽しそうな雰囲気がある」「何があるのか気になって行っ

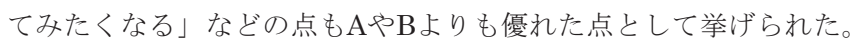
しかし「重なってごちゃごちゃしている」という意見は残った。

改善の仕方としては、Aの情報と Cのイラストとを織り交ぜた地図 をつくる方法、アプリ「100ninmap」にCのようなヴィジュアルを 加えるなどの方法があるだろう。ただし、そもそもどのような地図 がよい地図なのかは、街歩きの目的に依存する。また逆に、持って 歩く地図によって街歩きの体験は変わる。オノマトペマップを実用 化する際には、地図のターゲットや配布方法、地図を持った歩き方 なども含め、総合的にデザインをする必要があるだろう。

\section{5. つぶやきデータの分析}

\section{1. 地理的分析について}

ここから、得られたデータの分析を行なう。最初に、Fig. 2 を元に オノマトペの地理的な分布について述べる。

海に近い場所には海の音や波のきらめき、船などに関するオノマ トペが多数プロットされており、海から離れると車の音や人の声、 動物の鳴き声、食べ物などに関するオノマトペが多いことが見受け られる。線路沿いには電車の音が、住宅地内に散在する神社では鐘 の音などが記録されるというように、場所の性質に対応したオノマ トペがプロットされているようである。

ただし内容に関係なく配置だけを見ると、やや偏りが大きい。特 に、地図上で焼津市役所や焼津東小学校の左側に位置する通りや、 焼津市役所の上から内港へと伸びる通りにはかなりの数のオノマト ペが集中している。これは、焼津市役所が街歩きの発着地点だった ことが影響していると考えられる。また新港の右側や線路をまたぐ 高架橋の周辺（地図中央上）など、局所的にプロットが集中寸る場
所もいくつか見られる。友人同士の複数人で歩いた参加者が多かっ たことや、歩きながら随時立ち止まってつぶやくのではなく、たま たま長く滞留した場所で多数つぶやく傾向があったことなど、参加 者の行動の仕方がその要因の一つであろう。

つまり、つぶやきの地理的分布の偏りには、その場所の様相とは 直接関係しない要因がかなり影響している。したがって、このデー 夕に対して先に概観した以上の精緻な地理的な分析を行なっても、 得られる知見は限定的だと考えられる注7)。次節以降では、地理的な 分布傾向を分析寸るのではなく、集まったデータ全体をまとめて扱 い、街歩きとオノマトペという方法によって都市の様相のどのよう な側面が浮かび上がるのかを分析する。

なお地理的な分析を行なって有意な結果を得るためには、参加者 数を増やしたり、自由歩行ではなく各人の歩く範囲を指定したりす るなど、データ収集の段階から工夫が必要だと考えられる。この点 については今後の課題としたい。

\section{2. 感覚と表現についての分析}

\subsection{1. 分類}

オノマトペを分類した既往研究として、山梨23)や艼坂24)による五 感での分類がある。またオノマトペは擬音語・擬態語・擬情語から 成ることが一般的に知られている。以上の二つの分類を「感覚の分 類」「表現の分類」と呼び、本稿でも使用寸る。二つの分類は、似て いるようで異なる。感覚の分類は、参加者が五感のうちどの感覚で 様相を把握したのかを分類するものであり、表現の分類は結果的に つぶやかれたオノマトペの分類である。ごく単純化して言えば、街 歩き参加者へのインプットとアウトプットとの違いである。

実際の分類作業は、オノマトペだけではなく説明文も加味し、意 味内容を確認しながら行なった。感覚は基本的には五感をべースに 分類したが、いずれにも分類できないものがあった。それは空腹感 による「ぐうぐう」、歩くことを示す「てくてく」などで、外的な事 象に関係なく、自らの身体のみで感覚しているものである。このよ うな例は[身体]とすることにした。したがって、上述のインプットー アウトプット関係は必ずしも成り立たないことになる。

表現の分類は[擬音語][擬態語][擬情語]の三分法をベースに行な ったが、宇野ら25)が指摘しているように、これらのカテゴリーは中 心的成員と周辺的成員の存在するプロトタイプカテゴリーにすぎず、 明確な分類は難しい。たとえば「どーん」は一般的には大きな爆発 音や落下音を示寸擬音語と思われる。しかし富士山や大型船が見え たときにこの言葉を用いた参加者が複数いた。大きいという意味合 いによって、擬音語から擬態語へと転用されたものと考えられる。 この場合は[擬態語]に分類した。また「おおお～」「へえー」などは 自分の声や感情をそのまま記したもので、オノマトペとしては捉え にくいものかもしれない（擬音語としても擬情語としてもプロトタ イプ的ではない)。しかしこのような例が多く見られたことから、[自 分の声・感情]というカテゴリーをつくることにした。

分類結果を集計し、Table 2の感覚と表現のクロス表が得られた。 比較のため、文献1)〜4)の京都での経路歩行実験の研究において作 成した言葉の分類表を示す (Table 3)。

\subsection{2. 分類に基づく分析}

まず感覚について見てみる。人間は五感の中でも特に視覚が発達 しているとされ、Table 3でも視覚によって捉えられる要素が多い。 
Table 2 Cross tabulation by classification of sensation and expression 感覚・表現の分類によるクロス集計

\begin{tabular}{|c|c|c|c|c|c|c|c|c|c|c|c|}
\hline & \multicolumn{9}{|c|}{ 感覚の分類 classification of sensation } & \multirow[b]{2}{*}{$\begin{array}{l}\text { 計 } \\
\text { total }\end{array}$} \\
\hline & & $\begin{array}{l}\text { 視覚 } \\
\text { sight }\end{array}$ & $\begin{array}{l}\text { 聴覚 } \\
\text { sound }\end{array}$ & $\begin{array}{l}\text { 嗅覚 } \\
\text { smell }\end{array}$ & $\begin{array}{l}\text { 味覚 } \\
\text { taste }\end{array}$ & $\begin{array}{l}\text { 触覚 } \\
\text { touch }\end{array}$ & $\begin{array}{l}\text { 身体 } \\
\text { body }\end{array}$ & \begin{tabular}{|l|} 
複合 \\
multip
\end{tabular} & & $\begin{array}{l}\text { 不明 } \\
\text { nknown }\end{array}$ & \\
\hline \multirow{6}{*}{ 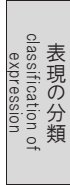 } & 擬音語 sound word & 17 & 234 & - & - & - & 3 & & & 2 & 258 \\
\hline & 擬態語 mimetic word & 116 & 2 & $\varepsilon$ & 9 & 6 & 21 & & & 6 & 169 \\
\hline & 擬情語 pseudo word & 5 & - & - & - & - & 6 & & & 2 & 17 \\
\hline & $\begin{array}{c}\text { 自分の声·感情 } \\
\text { own voice / emotion }\end{array}$ & 39 & 1 & - & 11 & 1 & 1 & & & 3 & 65 \\
\hline & 複合 multiple & 3 & - & - & - & - & 1 & - & & - & 4 \\
\hline & それ以外 other & 5 & 8 & 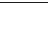 & 4 & - & 1 & - & & 1 & 20 \\
\hline & 計 total & 185 & 245 & c & 24 & & 33 & 1 & & 14 & 533 \\
\hline
\end{tabular}

Table 3 Classification of words in the author's study of the Walkthrough Experiment 経路歩行実験の研究での言葉の分類

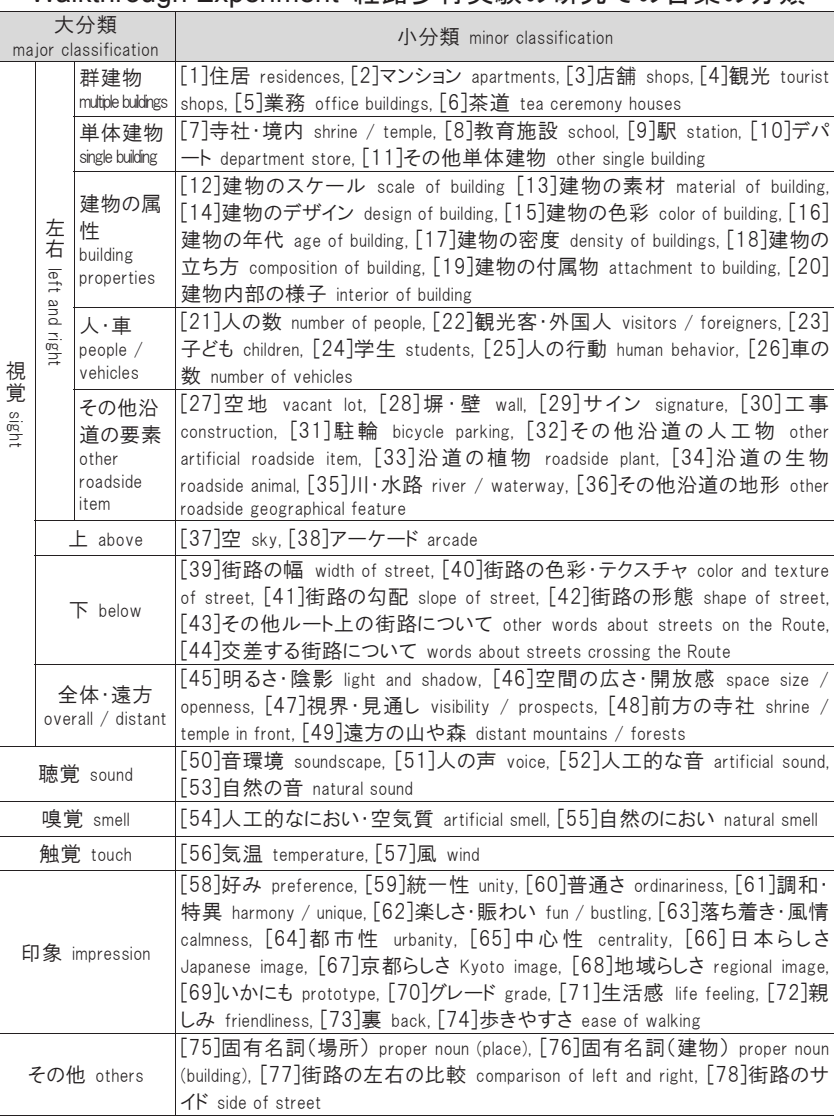

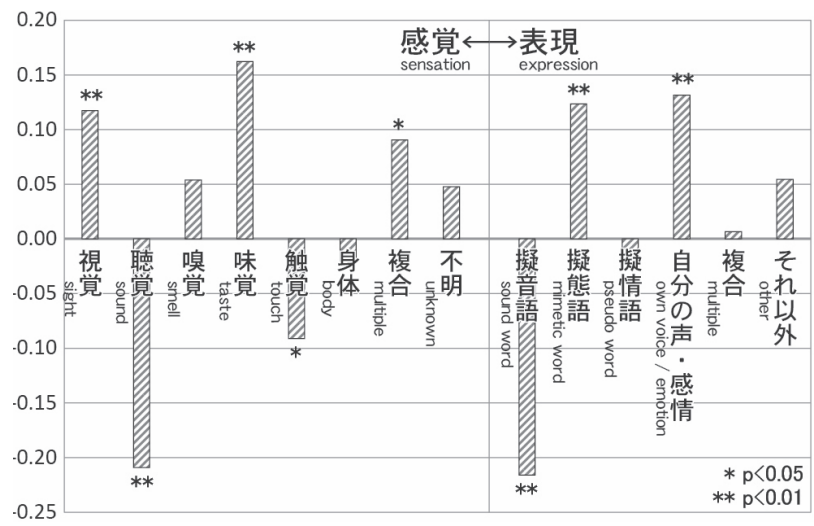

Fig. 6 Correlation coefficient between sensory / expression classification and impression evaluation 感覚・表現の分類と印象評価との相関係数

しかしTable 2の感覚の分類を見ると、[聴覚]が半数近くを占める。 オノマトペを用いることで、特に音に対する感覚が鋭くなると考え られる。記録方法が様相把握の仕方を変えているのである。[聴覚]に
次ぐのは[視覚]であるが、[身体]が3番目に多く、これもTable 3では ほぼ見られない。歩き始める前に「ドキドキ」し、「てくてく」と歩 き始め、空腹で「ペこぺこ」になり、飲食店に入って「もぐもぐ」 と食べて、最後は「へとへと」になる。このように身体の状態が行 動を変え、また記録内容にも影響する。

筆者らの様相論では、都市（客体）に対して人間（主体）は別個 であり独立していると考える主客二元論の立場は取らない。人間は 都市の中に内在しているのである。その際に、身体は都市と人間と の間のインタフェイスとなるものであり、様相の捉え方に少なから ず影響する。上に述べたような身体感覚によるオノマトペは、この 考え方を支持するものである注8)

次に表現の分類では、[擬音語]が半数近くある。そのほとんどは [聴覚]と対応し、擬音語が音を表現寸るものであることから当然の 結果である。しかし次に多い[擬態語]は、[擬音語]とは対照的に[視 覚]だけではなく[嗅覚][味覚][触覚]や[身体]によって感覚したこと がらも表現する。3番目に多いのは[自分の声・感情]である。視覚や 味覚、あるいはそれらの複合的な感覚で捉えたことが、感嘆や落胆 などを示す声として発せられる。

感覚と表現との関係に関して、興味深い事例について具体的に記 す。まず、オノマトペ欄は「フワフワーサクサク」であるが、説明 文には「パン屋」としか記されていないつぶやきである。実際にパ ンを食べたのなら、おそらくその旨を説明文として書くと思われる から、この参加者はパン屋を目視しただけであろう。つまり参加者 は食べてもいないパンの食感を記している。他にも壊れそうな古い 家を見て「ギシィ」、床屋を見て「チョキチョキ」など、実際には聞 いていないと考えられる音を記録した例が数多く見られた。この現 象には、記憶が大きく関係しているものと考えられる。われわれは パンの食感として「フワフワーサクサク」、床屋のはさみの音として 「チョキチョキ」という表現をプロトタイプとして記憶しており、実 際には聞かずとも、パン屋や床屋を見ただけでこれらの表現が思い 浮かぶのである。視覚と触覚や聴覚が、記憶を通じて、一種の共感 覚を起こしている。様相把握における記憶の役割の重要性について は、筆者らが以前の研究において強調した通りである26)。

また参加者が見たのはパン屋であるが、「フワフワーサクサク」は パンの食感である。パン屋を見てパンについて記録するという、メ トニミー現象であると言える。他にも、自動販売機を見て「チャリ ン」という小銭の音を記録する例などが見られた。

オノマトペを使用することで、目に見えるものを単にそのものと して捉えるだけではなく、音や食感にまで思いを馳せたり、隣り合 っている別のものを連想したりするなど、イメージが広がっている 様子が伺える。たとえば上記の「パン屋」の事例では、パン屋の建 物だけではなく、それを取り巻くパンやその食感といった状況が捉 えられている。様相の記録の射程も拡張されていると言える。

\subsection{3. 印象評価との関連性の分析}

次に、参加者がオノマトペを捉えたときに入力した5段階の印象 評価（「-2：悪い」〜「+2：よい」の5段階）を用いて、オノマトペ のカテゴリーと印象評価との関連性を調べる。本稿では、カテゴリ 一と印象評価との関連性の高さを表わすために、相関係数を用いる 注9)。各つぶやきについて各カテゴリーの語の使用の有無を $0,1 て ゙$ 表 現し、それと印象評価の值との間で相関係数を求めるのである。な 
お全データでの印象評価の平均值は0.925で、全体的にはオノマト ペで捉える事象に対してよい印象を持つことが伺える。したがって これから相関係数によって明らかにするのは、カテゴリー間の相対 的な差である。相関係数が負の值をとるからといって、印象評価も 負の值になっているとは限らない。

感覚、表現のカテゴリ一別の印象評価との相関係数をFig. 6に示 す。相関係数の絶対值は最大 0.22 程度ではあるが、サンプル数が 533 と大きいため、統計的に有意な相関が8つ得られた。まず目につくの が、[聴覚][擬音語]の印象評価との相関係数が負の值となることであ る。騒音や雑音が含まれるためだと考えられる。印象評価との相関 係数が高いのは、感覚では[視覚]と[味覚]、表現では[擬態語]と[自分 の声・感情]であった。これらについては、次節の内容と併せて後に 分析する。

\section{3. 対象についての分析}

\subsection{1. 分類}

次に、オノマトペが何の音や動きなどを表現したのかということ について分析する。これをオノマトペの「対象」と呼ぶ。対象は、 いわばインプットにつながる外的刺激である。ただし、単純な主客 二元論の図式が成り立たないことは先にも述べた通りである。

対象は、主にオノマトペの説明文の内容から判断した。先の感覚 と表現の分類の際には533のデータをすべて一意に分類し、複数の 感覚や表現が混じる場合には[複合]としたが、対象の分類では一つ のデータが複数カテゴリーに入ることを許容した。その意味ではカ テゴリーというよりラベルと呼んだ方が直感的である。

対象の分類には、五感や擬音語・擬態語・擬情語のような一般的 に知られた分類法がない。筆者らの以前の研究によるTable 3を援用
するのがよいようにも思われるが、自由記述とオノマトペ、京都と 焼津などの条件の違いによって参加者の記録内容もかなり異なって

Table 4 Classification of targets of onomatopoeia 対象の分類

\begin{tabular}{|c|c|c|c|}
\hline $\begin{array}{c}\text { 大分類 } \\
\text { major } \\
\text { classification }\end{array}$ & $\begin{array}{c}\text { 小分類 } \\
\text { minor classification }\end{array}$ & \begin{tabular}{|c|} 
大分類 \\
major \\
classification
\end{tabular} & $\begin{array}{c}\text { 小分類 } \\
\text { minor classification }\end{array}$ \\
\hline \multirow{8}{*}{$\begin{array}{l}\text { 建物 } \\
\text { building }\end{array}$} & 飲食店 restaurant & \multirow{3}{*}{$\begin{array}{l}\text { 音 } \\
\text { sound }\end{array}$} & 音楽 music \\
\hline & 食料品店 grocery store & & カメラ camera \\
\hline & 温泉·足湯 hot spring & & 静寂 silence \\
\hline & その他店舗 other shop & \multirow{2}{*}{\begin{tabular}{|c|}
$\begin{array}{c}\text { 他者 } \\
\text { other people }\end{array}$
\end{tabular}} & 人の声 voice \\
\hline & 住宅 residence & & 人の行動 human behavior \\
\hline & 社寺 temple / shrine & \multirow{6}{*}{$\begin{array}{l}\text { 自分 } \\
\text { self }\end{array}$} & 歩行 walk \\
\hline & 教育施設 school & & その他行動 other behavior \\
\hline & その他建物 other building & & 空腹 hungry \\
\hline \multirow{9}{*}{$\begin{array}{c}\text { 沿道の } \\
\text { もの } \\
\text { roadside item }\end{array}$} & 信号 traffic sign & & 満腹 full \\
\hline & 看板 signboard & & $\begin{array}{l}\text { その他体調 other physical } \\
\text { condition }\end{array}$ \\
\hline & 港湾の機械 harbor machinery & & 感情のみ just emotion \\
\hline & 工事 construction & \multirow{3}{*}{$\begin{array}{c}\text { 水 } \\
\text { water }\end{array}$} & 海 ocean \\
\hline & 旗 flag & & 波 wave \\
\hline & 風鈴 wind chime & & 川川 river \\
\hline & 鐘 bell & \multirow{3}{*}{$\begin{array}{c}\text { 植物·山 } \\
\text { plant } / \\
\text { mountain }\end{array}$} & 近い植物 nearby plant \\
\hline & 銅像 statue & & 富士山 Mt. Fuji \\
\hline & その他沿道のもの other roadside item & & その他山 other mountain \\
\hline \multirow{2}{*}{$\begin{array}{l}\text { 足下 } \\
\text { below }\end{array}$} & 地面 ground & \multirow{5}{*}{$\begin{array}{l}\text { 動物 } \\
\text { animal }\end{array}$} & 鳥 bird \\
\hline & 通り street & & 魚 fish \\
\hline \multirow{6}{*}{$\begin{array}{c}\text { 乗り物 } \\
\text { vehicle }\end{array}$} & トラック truck & & 凍った魚 frozen fish \\
\hline & その他車 other vehicle & & 犬 dog \\
\hline & 電車 train & & その他生き物 other animal \\
\hline & 新幹線 Shinkansen & \multirow{3}{*}{$\begin{array}{l}\text { 天候など } \\
\text { climate, etc. }\end{array}$} & 風 wind \\
\hline & 船 ship & & 気温 temperature \\
\hline & 飛行機·ヘリ aircraft & & 天候 climate \\
\hline \multirow{6}{*}{$\begin{array}{c}\text { 飲食物 } \\
\text { Food and } \\
\text { drink }\end{array}$} & 魚を使つた食べ物 food made of fish & \multirow{2}{*}{$\begin{array}{l}\text { その他 } \\
\text { other }\end{array}$} & その他 other \\
\hline & パン bread & & 不明 unknown \\
\hline & アイス ice cream & & \\
\hline & その他食べ物 other food & & \\
\hline & コーヒー coffee & & \\
\hline & その他飲み物 other drink & & \\
\hline
\end{tabular}

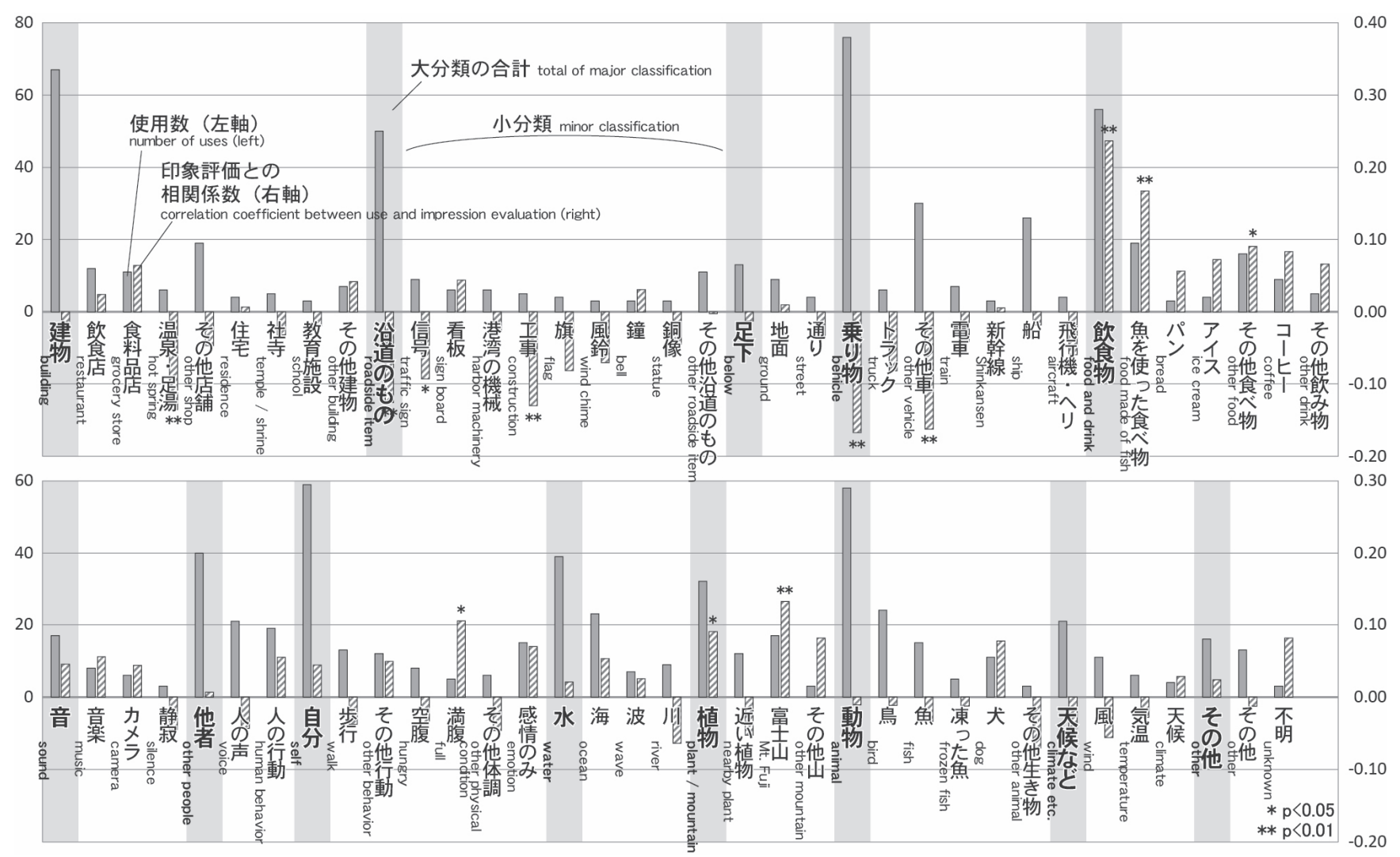

Fig. 7 Number of uses of target classification and correlation coefficient between use and impression evaluation 対象の分類の使用数之、印象評価との相関係数 
いたため、新たに分類表を作成した（Table 4)。この表は分類に先 立ち所与のものとして決めていたものではなく、データを見ながら 探索的につくりあげたものだ。個々のデータに仮のラベルをつけ、 一通り終わったらラベルの使用数を集計し、使用数の少ないラベル の合併、多すぎるラベルの分割などを行なうことで、各ラベルの使 用数が分析に適したものになるよう調整していった。

\subsection{2. 分類に基づいた分析}

ラベルの使用数と、ラベルと印象評価との相関係数とをFig. 7 まとめた。大分類と小分類とを両方示している。

まず、Table 3 とTable 4とを比べると、かなり異なった構成とな っている。オノマトペの表現に[自分の声・感情]が多いことに対応し て、Table 4では[自分]という大分類があり、Fig. 7を見ると使用数 も高い。またTable 4では魚や海、船に関する言葉が多く、焼津とい う街の特性が反映されている。逆にTable 3にあってTable 4にはな いのが、建物の属性や、その場の全体的な印象を表わ寸カテゴリー である。オノマトぺは基本的に何らかの対象があって発せられるも のであり、その場の全体的な在り方を直接的に捉えることは少ない と言える。ただし諸対象について表現したオノマトペを集積するこ とで、その場所の様相を捉えることができると筆者は考えている。

大分類では[乗り物]が最多を占め、[建物][自分][動物][飲食物]が続 く。印象評価との相関係数は[飲食物]において高い值となり、Fig. 6 での[味覚]の值の高さと符合する。街歩きの感想（Table 1）でも飲 食物に言及するものは多く、食は都市の様相を構成する重要な要素 であると言える。印象評価との相関係数が負の值となるのは[トラッ ク][その他車]や[工事]など、騒音を発するものが多い。

建物の小分類を見ると、各種の店舗が大多数を占める主10)。実際に は、歩行範囲内には店舗よりも住宅の方がかなり多く建っているの であるが、住宅についてはほとんど言及されず、参加者の関心は店 舗に集中寸る。参加者の記録によって映し出されるのは都市の物理 的な姿そのものではなく、あくまで参加者が捉えた認識の上での都 市なのである。

\section{4. 文字の使用についての分析}

通常、オノマトペは「バンバン」のように2文字程度の単位を重畳 したものが多く、「バン」のように単独の場合もある。したがって、 通常のオノマトペの平均文字数は $3 \sim 4$ 文字程度になると考えられ る。ところが今回得られたデータの平均文字数は、5.55文字であっ た。その要因を分類したのがTable 5である。同じ文字を重㸚るパタ ーン、単位の重畳を3回以上にするパターン、そして異なるオノマト

\section{ペを組み合わせるパターンが見られた。}

同じ文字や単位を繰り返す事例は、オノマトペが指し示す対象の 音や動きの時間的持続性を表現していると推測できるものが多い。 たとえば船のエンジン音を聞いたときに「ぶろろろ」ではなく「ぶ ろろろろろろろろろろろろろろ」と記録しているのは、音の長さを 表わしていると考えられる。実際の状況を体験せずに書いたり話し たりする場合は「ぶろろろ」と表現するであろうが、実際の都市に おける音や動きはより持続的な場合が多いのではないだろうか。他 に、繰り返しが参加者の感情の強さの度合いを反映していると考え られるケースもある。たとえば「おー」よりも「うおーーーーーー 一」の方が、書き手の驚きが読み取れる。

複数のオノマトペを組み合わせるパターンは、一つの状況を複数
Table 5 Factors that increase the number of characters in an onomatopoeia オノマトペの文字数が長くなる要因

\begin{tabular}{|c|c|c|}
\hline 種類 classification & 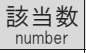 & 具体例 example \\
\hline $\begin{array}{l}\text { 母音または伸ばし棒を2回以上重畳 } \\
\text { repeat vowel or stretching bar more than once }\end{array}$ & 75 & $\begin{array}{l}\text { ぴょーーーん, ブワアアアーー } \\
\text {-ー }\end{array}$ \\
\hline $\begin{array}{l}\text { 母音以外の1文字を2回以上重畳 } \\
\text { repeat one letter other than a vowel more than once }\end{array}$ & 31 & $\begin{array}{l}\text { ドドドドーン, ぶろろろろろろろろろ } \\
\text { ろろろろ }\end{array}$ \\
\hline $\begin{array}{l}\text { 2文字以上の単位を3回以上重畳 } \\
\text { repeat unit of two or more letters more than twice }\end{array}$ & 41 & $\begin{array}{l}\text { トントントントン, くるくるくるくるくる } \\
\text { くるくる }\end{array}$ \\
\hline $\begin{array}{l}\text { 2つの異なるオノマトペの組み合わせ } \\
\text { combine two different onomatopoeias }\end{array}$ & 34 & $\begin{array}{l}\text { ギラギラピカピカ, ペコペコグゥ } \\
\text { 一グゥー }\end{array}$ \\
\hline $\begin{array}{l}\text { 3つの異なるオノマトペの組み合わせ } \\
\text { combine three different onomatopoeias }\end{array}$ & 7 & $\begin{array}{l}\text { ツヤツヤテカテカピカピカ, ペコ } \\
\text { ペコパンパンペコリ }\end{array}$ \\
\hline 記号 $(!, \cdots)$ symbols & 10 & 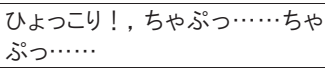 \\
\hline 上記いずれも該当なし none of the above & 331 & ピューピュー, カシャッ \\
\hline
\end{tabular}

の表現で描写したものが多い。「ツヤツヤテカテカピカピカ」は刺身 の輝きを、「ヒンヤリスースー」は寒さを、オノマトペの組み合わせ により複合的に記録している。他に、食後の居眠りを表現した「ポ カポカうとうと八ッ」や、神社参拝時の二礼二拍手一礼の動作を表 現した「ペコペコパンパンペコリ」などは、組み合わせによって行 為のシークエンスを表現した興味深い例である。

オノマトペの創造性についてはいくつか既往研究がある。井上は、 オノマトペが多義的であるがゆえに意味がメトニミー的に拡張され る現象を分析している27)。5.2.1.で述べた「どーん」はその例である。 大塚ら 28)や山田ら 291 は新しいオノマトペを創作することによる表現 の可能性を探っている。本研究ではTable 5のように、既存オノマト ペをアレンジして文字数を伸ばす例が多数見られた。都市の時間的 な持続や推移、状況の多面性などを反映した創作が行なわれている。

\section{6. おわりに}

\section{1. 本稿の成果}

本稿では静岡県焼津市における街歩きで、スマートフォンアプリ を利用して主にオノマトペによって都市の様相を記録してもらい、 そのデータに基づいて焼津の街の様相を記述・分析した。4章で見た ように、オノマトペを見つけながら街を歩くという体験は発見に富 むものであり、作成したオノマトペマップも街の雰囲気を伝え、街 歩きに人をいざなう魅力を持っていることがわかった。さらに5章 では感覚・表現・対象の分類や印象評価との関係の分析などを行な い、多様な成果を得た。以上より、オノマトペを用いた街歩きによ る都市の様相の記録、そのデータを用いた様相の記述・分析という 一連の研究方法は、一定の妥当性をもつものであったと考えられる。 また本研究は、理論と方法の大きな枠組みは筆者らが以前行なっ た文献1） 4)の研究と共通しているが、特に自由記述とオノマトペ というツールの違いにより、浮かび上がる都市の様相についてはさ まざまな差異が見られた。まず様相を捉える感覚は、自由記述を用 いた場合には視覚が第一に用いられるのに対してオノマトペでは聴 覚が優越する。他には身体的感覚による記録も増える。次に才ノマ トペが捉える対象に関しては、建物の属性や、その場の全体的な䨌 囲気や印象を直接的に表わ寸ことは、自由記述に比べてかなり少な くなる。対象と印象評価との相関係数に関しては、車や工事など騒 音を出すものについては低く、食べ物については高いという傾向が 見られる。また船や魚などについての記録が多くなっているが、こ れは自由記述とオノマトペという違いだけではなく、京都と焼津と 
いう実験対象地の違いを強く反映しているものと考えられる。さら に文字の使用についての分析では、繰り返しや組み合わせなどによ ってオノマトペをアレンジし、都市における音や動きの持続や推移、 都市の状況の多面性などを表現する例がかなり多いことが明らかに なった。これは、使用する言葉をオノマトペに制限したからこそ生 まれた創作であると言える。

本稿の研究方法は、焼津以外の都市にも応用可能である。特に、 都市のサウンドスケープの可視化や、視覚だけでは捉えられないよ うな街の魅力を探すワークショップなどにおいて、この研究方法は 有効になると考えられる。1.1.で述べたような地方都市の知られざ る魅力を掘り起こすための、一つの方法にもなるだろう。

\section{2. 今後の課題}

4章で述べたように、焼津オノマトペマップの表現については改 善の余地がある。観光地図としてのオノマトペマップの実用化も見 据えて、さらに検討を重㸚たい。また5.1.で述べたように地理的偏り がない十分な量のデータ収集と、それに基づく地理的分析について も今後の課題である。データ収集に関しては、街歩きではなく、文 献16)において仲村らが行なったようなインターネット上のデータ を利用するという手段についても検討の余地がある。

また本稿では、捉えられる都市の様相が自由記述やオノマトペと いった記録ツールによって異なることが示された。これは自由記述 やオノマトペ以外の、たとえばメタファ、川柳、スケッチなどの記 録ツールを用いれば、また違った側面から都市の様相を捉えられる ことを示唆している。記録ツールと把握される都市の様相との関係 性については、引き続き探求を続けたいと考えている。

\section{謝辞}

本研究は、静岡市・焼津市地域課題解決事業「若者への魅力ある 情報の発見と発信方法」(代表 : 山田雅敏) の助成により行ないまし た。常葉大学の山田雅敏先生、焼津市役所の櫻井芳之様には街歩き の実施に関して多大なご協力をいただきました。また100ninmap projectの共同研究メンバーにはアプリ開発などについて助力をい ただきました。以上、記して感謝いたします。

\section{参考文献}

1) Yusuke Kita et al. : Description of Urban Modalities by Walkthrough Experiments - Study on Reading Urban Modalities and Their Design Methods Part 1, Journal of Architecture and Planning (Transactions of AIJ), Vol.75, No.651, pp.1159-1168, 2010.5. (in Japanese) 北雄介・門内輝行 : 経路歩行実験による都市の様相の記述一都市の様相 の解読とそのデザイン方法に関する研究 (その1), 日本建築学会計画系 論文集, Vol.75, No.651, pp.1159-1168, 2010.5.

2) Yusuke Kita et al. : Analysis of Urban Modalities Based on Modal Factors - Study on Reading Urban Modalities and Their Design Methods Part 2, Journal of Architecture and Planning (Transactions of AIJ), Vol.76, No.661, pp.625-634, 2011.3. (in Japanese) 北雄介・門内輝行 : 様相因子による都市の様相の分析一都市の様相の解 読とそのデザイン方法に関する研究 (その 2), 日本建築学会計画系論文 集, Vol.76, No.661, pp.625-634, 2011.3.

3) Yusuke Kita et al. : Analysis of Urban Modalities based on Properties of Edges and Areas - Study on Reading Urban Modalities and Their Design Methods Part3, Journal of Architecture and Planning (Transactions of AIJ), Vol.76, No.666, pp.1433-1442, 2011.8. (in Japanese)

北雄介・門内輝行 : エッジ, エリアの特性による都市の様相の分析一都市
の様相の解読とそのデザイン方法に関する研究 (その 3 ) ，日本建築学会 計画系論文集, Vol.76, No.666, pp.1433-1442, 2011.8.

4) Yusuke Kita et al. : Analysis and Modeling of Urban Modalities based on Frame Theory - Study on Reading Urban Modalities and Their Design Methods Part4, Journal of Architecture and Planning (Transactions of AIJ), Vol.79, No.696, pp.421-430, 2014.2. (in Japanese)

北雄介・門内輝行 : フレーム概念に基づく都市の様相の分析とモデル化 一都市の様相の解読とそのデザイン方法に関する研究 (その 4)，日本建 築学会計画系論文集, Vol.79, No.696, pp.421-430, 2014.2.

5) Hiroshi Hara : Space <From Function to Modality>, Iwanami Shoten, p.224, 1987. (in Japanese)

原広司：空間〈機能から様相へ〉, 岩波書店, p.224, 1987.

6) Akira Kanao, et al. : Study on Urban Domain using Model Theory: Part 5 The Curvature of the Path in Urban Space, Summaries of Technical Papers of Annual Meeting, Architectural Institute of Japan, F, pp.455456, 1987. (in Japanese)

金尾朗・原広司・藤井明・曲淵英邦・工藤和美 : 都市領域の様相論的研 究 : その5 都市における経路の曲折性, 日本建築学会大会学術講演梗概 集. F, pp.455-456, 1987.

7) Hidekuni Magaribuchi, et al. : A Study on Urban Domain using Modal Theory: Part 15: Topological Model of Taxi Movement in Tokyo, Summaries of Technical Papers of Annual Meeting, Architectural Institute of Japan, F, pp.439-440, 1991. (in Japanese)

曲㴊英邦・原広司・藤井明・高橋元子 : 都市領域の様相論的研究 : その 15 東京におけるタクシー運行の位相空間モデル, 日本建築学会大会学術講 演梗概集. F, pp.439-440, 1991.

8) Lynch, K. : The Image of the City, The MIT Press, 1960.

9) Appleyard, D., Lynch, K. and Meyer, J.R. : The View from the Road, The MIT Press, 1971.

10) Hideki Shimizu : Image Structure of the City, Gihodo Shuppan, 1979 (in Japanese)

志水英樹 : 街のイメージ構造, 技報堂出版, 1979 .

11) Toru Funakoshi et al. : A Study of Partitive Points-Analyses And Physical-Analysis on Approach Spaces of SHINTO Shrines: Study on Approach Spaces of SHINTO Shrines (Part I), Journal of Architecture, Planning and Environmental Engineering (Transactions of AIJ), No.384, pp.53-61, 1988.2. (in Japanese)

船越徹・積田洋・清水美佐子 : 参道空間の研究 : その 1 . 参道空間の文節 と空間構成要素の分析（分節点分析・物理量分析）, 日本建築学会計画系 論文報告集, No.384, pp.53-61, 1988.2.

12) Hisato Tanaka : Study on the Management and Analysis of Workshop for Misumi Elementary School About Misumi-Nishi Port, Kumamoto University Policy Research, No.7, pp.25-32, 2016. (in Japanese) 田中尚人：三角西港における小学生を対象としたワークショップの成果 に関する考察, 熊本大学政策研究, No.7, pp.25-32, 2016.

13) Tazuko Ouchi : Study on Regional Planning Based on City Walk Regarding Disaster Prevention, Bulletin of Edogawa University, No.23, pp.197-210, 2013. (in Japanese)

大内田鶴子：防災まち歩き社会実験によるまちづくりの研究，江戸川大 学紀要, No.23, pp.197-210, 2013.

14) Hiroshi Omori et al. : Slot Map: Town Map and Collective Intelligence of Image about Town Integrating Snapshot-Location-Texts, Journal of Architecture and Planning (Transactions of AIJ), Vol.78, No.683, pp.159-166, 2013.1. (in Japanese)

大森宏・羽生和紀・山下雅子 : SLoTマップ：スナップショット・位置・ テキストによる印象の集合知と街歩きマップ,日本建築学会計画系論文 集, Vol.78, No.683, pp.159-166, 2013.1.

15) Sugiura Lab. : Pedaling a Bicycle / Cha-reading Notation, Journal of Architecture and Building Science, Vol.124, No.1595, pp.16-17, 2009. (in Japanese)

昭和女子大学杉浦研究室 : 東京をこぐ/チャリーディング・ノーテーシ ヨン, 建築雑誌, Vol.124, No.1595, pp.16-17, 2009.

16) Tetsuaki Nakamura et al. : Which Sense does an Onomatopoeia Belong to?, Research Meeting on Interactive Information Access and Visual Mining, SIG-AM-04-01, pp.1-8, 2013. (in Japanese) 
仲村哲明・宮部真衣・荒牧英治: オノマトペが属する五感の推定，人工知 能学会インタラクティブ情報アクセスと可視化マイニング研究会（第 4 回）, SIG-AM-04-01, pp.1-8, 2013.

17) Ken Ishibashi et al. : Evaluation of Human Impressions regarding Sizzle Words for Rice Crackers:-A Focus on Onomatopoeias-, Journal of the Japanese Society for Artificial Intelligence, Vol.30, No.1, pp.229236, 2015. (in Japanese)

石橋賢・深瀧創・宮田一乘 : 米菓を対象としたシズル語の印象評価 一オ ノマトペを中心に一, 人工知能学会論文誌, Vol.30, No.1, pp.229-236, 2015 .

18) Shizuka Sato et al. : Proposal for a Song Video Search System Model on the Web using Onomatopoeia, IPSJ SIG Technical Report, Vol.2013DBS-157, No.13, pp.1-6, 2013. (in Japanese)

佐藤静香・児玉英一郎・王家宏・高田豊雄 : オノマトペを利用したWeb上 からの楽曲動画検索システムモデルの提案, 情報処理学会研究報告デー タベースシステム, Vol.2013-DBS-157, No.13, pp.1-6, 2013.

19) Yusuke Kita et al. : Study on Description of Urban Modality Using Free Writing Data with Positional Information: Comparison between "Walkthrough Experiment" and "100ninmap in Kyoto", Summaries of Technical Papers of Annual Meeting AIJ Kinki Branch, Vol.54, pp.573576, 2014. (in Japanese)

北雄介・宮部真衣・荒牧英治: 位置情報つき自由記述データを用いた都市 の様相記述に関する考察一「経路歩行実験」と「100人でつくる京都地図」 の比較を通して一, 日本建築学会近畿支部研究報告集 ·計画系, Vol.54, pp.573-576, 2014.

20) Hiroshi Omori et al. : Slot Map: Town Map and Collective Intelligence of Image about Town Integrating Snapshot-Location-Texts, Journal of Architecture and Planning (Transactions of AIJ), Vol.78, No.683, pp.159-166, 2013.1. (in Japanese)

大森宏・羽生和紀・山下雅子 : SLoTマップ：スナップショット・位置・ テキストによる印象の集合知と街歩きマップ, 日本建築学会計画系論文 集, Vol.78, No.683, pp.159-166, 2013.1.

21) Chie Fukada et al. : World of Conceptualization and Meaning, Kenkyusha, pp.124-125, 2008. (in Japanese) 深田智・仲本康一郎：概念化と意味の世界,研究社, pp.124-125, 2008.

22) Yaizu city : Yaizu Sightseeing Road Map, 2014. (in Japanese) 焼津市 : 焼津観光ロードマップ, 2014.

23) Masaaki Yamanashi : Metaphor and Understanding, University of Tokyo Press, p.84, 1988. (in Japanese) 山梨正明 : 比喻と理解, 東京大学出版会, p.84, 1988 .

24) Naoyuki Osaka (ed.) : Research on Sensational Words, Shinchosha, p.5, 1999. (in Japanese)

苧阪直行編著 : 感性のことばを研究する一擬音語・擬態語に読む心のあ りか, 新曜社, p.5, 1999 .

25) Ryoko Uno et al. : Two Boundaries of Onomatopoeia Emerging from Web Corpus, Range of Onomatopoetic Research, Hitsuji Shobo, p.123, 2013. (in Japanese)

宇野良子・鍛冶伸裕・喜連川優：ウェブコーパスの広がりから現れるオノ マトペの $2 つ の$ 境界, オノマトペ研究の射程 近づく音と意味, ひつじ書 房, p.123, 2013

26) Yusuke Kita et al. : Analysis and Modeling of Urban Modalities based on Frame Theory - Study on Reading Urban Modalities and Their Design Methods Part4, Journal of Architecture and Planning (Transactions of AIJ), Vol.79, No.696, pp.421-430, 2014.2. (in Japanese)

北雄介・門内輝行 : フレーム概念に基づく都市の様相の分析とモデル化 一都市の様相の解読とそのデザイン方法に関する研究 (その 4 ), 日本建 築学会計画系論文集, Vol.79, No.696, pp.421-430, 2014.2.

27) Kazuko Inoue : Ambiguity and creativity of onomatopoeia, Range of Onomatopoetic Research, Hitsuji Shobo, pp.203-216, 2013. (in Japanese)

井上加寿子 : オノマトペの多義性と創造性, オノマトペ研究の射程 近づ く音と意味, ひつじ書房, pp.203-216, 2013.

28) Yuko Otsuka et al. : Studies of Expressions to Taste Japanese Sake by Creating Onomatopoeia, JSAI2015 Proceedings, Vol.29, pp.1-4, 2015. (in Japanese)
大塚裕子・諏訪正樹・山口健吾: 創作オノマトペによる日本酒を味わう表 現の研究, 人工知能学会全国大会論文集, Vol.29, pp.1-4, 2015.

29) Kaori Yamada et al. : Design Support by Inventive Mimetic Word for Synthetic Motion Design, Journal of the Science of Design, Vol.63, No.2, pp.49-54, 2016. (in Japanese)

山田香織・工口陽平・田浦俊春 : 創作擬態語による動きの表現とその合成 によるデザイン支援, デザイン学研究, Vol.63, No.2, pp.49-54, 2016

注

注1）さらに、日本語は英語や中国語など他の言語に比べてオノマトペ(特に 擬態語）の語彙が多いことが知られている（文献24），pp.23-26.他）。した がってオノマトペマップは、特に我が国において有効な様相の記述方法で あると言える。

注2) https://twitter.com/

注3）この後の分析の基本的な考え方は、個々の参加者のつぶやきデータを個 別に扱うのではなく、全ての参加者のデータを集計して統計的に処理する ことで、参加者間のつぶやき件数の偏りの影響を排してなるべく一般的な 知見を得ようというものである。しかし実際には、つぶやき件数の多い参 加者のつぶやきが分析結果により強く影響するのは確かである。したがっ て本稿で述べる分析結果は、参加者間の偏りを前提としたものであり、完 全に一般的な傾向を捉えたものではない。

本稿のような参加者の自発性に任せてデータを集める方法では、この弊害 は避けられない。データの偏りの解決のためには、5.1.で地理的な偏りの解 消に関して述べたのと同様に、データ収集段階から工夫が必要だと考えら れる。

注4）基本的に4.2.の感覚の分類に準じたが、説明なしでは意味がわかりづら いと思われる[身体][不明]は割愛し、[複合]のものは[視覚][聴覚][嗅覚][味 覚][触覚]のうちもっとも意味合いの強いと思われるものに分類した。

注5) https://www.100ninmap.com/images/maps/yaizu_onomatopee_map.pdf 注6）自由記述をコーディングし、参加者の1割にあたる4名以上の回答数のあ ったもののみを表にした。

注7）地理的分析が難しい理由をデータの偏りの他にもう1点挙げると、分析 の軸となる概念の設定がしづらいことがある。以前の研究 (文献1）４））で は、「経路」という概念を軸に分析をすることができた。これは、都市にお ける人の経験を経路に沿った異なる世界間の横断だと考え、世界の移り変 わる境界で様相が強く把握される、と考えるものである。そして「経路歩 行実験」の被験者に共通のルートを歩いてもらったことから、すべての被 験者の経験した経路は同一のものと見做すことができ、被験者の記録をす ベて重ね合わせた上で、ルート上にあらわれる境界や領域について分析す ることができた。しかし今回の場合は街歩き参加者の通ったルートが不明 である上に、そのルートは参加者によって別々である。したがって、経路 という概念モデルは分析に使用できない。当然今回のデータについても、 5章で行なう諸々の分類に基づいて地理的な分布傾向を抽出したり、街路や 海などの都市構造との関係を分析したりすることはできる。しかし経路の ような、人間の経験に基づいた抽象的なもので、かつ分析にも有効な概念 モデルを提示することは、面的な自由歩行から得られた記録データを扱う 場合において、重要な課題である。

注8）他に、Table 2では[味覚]が一定数あるのに対し、Table 3では味覚に関す るカテゴリーがないことが指摘できる。これは、今回の街歩きでは途中に 昼食時間を挟んだが、文献1)〜4)の実験時はそうではなかったことが主要 な要因であると考えられる。

注9）カテゴリーごとに印象評価の平均值をとるのが一般的な方法であるが、 それでは成員の少ないカテゴリーではサンプル数が減り、統計的信頼性が 低くなる。それに対しカテゴリーに当てはまるか否かの 0,1 の数列と印象評 価との相関係数を求めれば、サンプル数は実質的に、全データ数である533 で固定される。成員の少ないカテゴリーでは、相関係数は0に近い值をとり やすくなる。平均值を用いた場合のように極端に大きな值や小さな值とな ることはなく、検定では有意な相関とならない。以上の理由から、本稿で は相関係数を分析に用いることとした。

注10)店舗の中で[温泉・足湯]が、印象評価との相関係数が低いことが目につ くが、これは焼津駅前の足湯がこの日に休業していたことによる。 


\section{DEPICTION AND ANALYSIS OF URBAN MODALITY \\ BASED ON CITY WALKS USING ONOMATOPOEIA}

\section{Yusuke KITA*1}

${ }^{* 1}$ Lect., Leading Graduate School of Design, Center for Educational Program Promotion in Graduate School, Kyoto Univ., Dr.Eng.

Both the atmosphere and the quality of cities have been receiving increasing attention these days. The cities of today are evaluated not only by what they have, but also by what they are- how they "feel." However, the qualitative aspects that we feel in cities are so vague that they are difficult to quantify or visualize. To address this, the authors have been implementing studies related to "urban modality," which indicates the total mode of a city. Urban modality manifests itself as not only as that which is visible—buildings, trees, people, traffic and so on; but also by that which is invisiblethe sounds, smells, breezes, and general atmosphere and feel of a city.

In order to depict urban modality in a visual manner, we conducted a city walk. The walk was conducted on February 2, 2017 in Yaizu, Shizuoka Prefecture, with 40 participants. Each participant walked around the city with a smart phone to input and transmit onomatopoeia - their descriptions and their impressions at the time (on a five-point scale) using an application named "100ninmap." The data were transmitted to a server along with the locations obtained by the smart phone, and visualized on a map. We were thus able to obtain a total of 533 pieces of data. By classifying onomatopoeia based on the five senses, and preparing illustrations based on subject expression, we developed the "Yaizu Onomatopoeia Map."

It was made clear by a questionnaire survey that the participants of the city walk enjoyed finding onomatopoeias. In addition, we verified what impressions people received from the onomatopoeia map in a comparison experiment with general sightseeing maps. The results revealed that the onomatopoeia map transmitted the atmosphere of the city very well and made people want to walk around the city, even though the onomatopoeia map was less detailed than existing sightseeing maps. This indicated that our goal of developing a new sightseeing map through visualization of urban modality was basically met.

Next, we analyzed the obtained text data itself and showed that the data were quantifiable and that they offered information about urban modality. First, we categorized data by which sense the participants grasped urban modality and by what kind of representation they used—such as imitative words and mimetic words. It transpired that more information about sounds is captured by using onomatopoeia than by using free words. Next, we classified the subjects indicated by onomatopoeic words. Categories obtained by the classification reflect the characteristics of Yaizu city. Then we calculated a correlation coefficient between use and impression evaluations for each category. Categories related to foods are positively correlated with impressions, while categories related to noise are negatively correlated with it.

The research method used in this study to make maps based on city walks using onomatopoeia can be adapted to other cities for depicting and analyzing urban modality. 